\title{
Penerapan Pendekatan Concrete Representational Abstract (CRA) untuk Meningkatkan Pembelajaran Matematika tentang Pengukuran pada Siswa Kelas IV SDN 1 Jerukagung Tahun Ajaran 2016/2017
}

\author{
Teguh Prasetyo', ${ }^{1}$ ahyudi ${ }^{2}$, Rokhmaniyah $^{3}$ \\ 1,2,3Universitas Sebelas Maret \\ goprasetyo@yahoo.com
}

\section{Article History}

accepted 01/06/2019

published 01/08/2019

\begin{abstract}
The objectives of this study are: (1) to describe the steps in applying the concrete representational abstract approach (CRA), (2) to describe the improvement of learning about measurement through the application of the concrete representational abstract approach (CRA), and (3) describe the obstacles and solutions in applying the concrete approach representational abstract (CRA) to improve learning about measurement in fourth grade students of SDN 1 Jerukagung.. This research is a collaborative Classroom Action Research (CAR) conducted within three cycles through stages: planning, action, observation, and reflection. Subjects of the research were fourth grade students of SD Negeri 1 Jerukagung totaling 21 students. Techniques of collecting data were learning outcomes test, observation, and interview. Validity of data in this research was analyzed using triangulation of sources and triangulation of technique. The result of this research showed that the implementation of CRA approach can improve improve learning about the measurement of fourth grade students of elementary schools. It was proved by the increase of learning mastery percentage in the first cycle, the results of observations of the teacher obtained a percentage of $65.49 \%$, with the number of students who complete is $73.81 \%$. In the second cycle, the results of observations of the teacher obtained a percentage of $75.00 \%$, with the number of students who complete is $78.57 \%$. In the third cycle, the results of observations of the teacher obtained a percentage of $83.92 \%$, with the number of students who complete is $92.86 \%$.
\end{abstract}

Keywords: concrete, representational, abstract, learning, measurement

\begin{abstract}
Abstrak
Penelitian ini bertujuan untuk (1) mendeskripsikan langkah-langkah penerapan pendekatan concrete representational abstract (CRA), (2) mendeskripsikan peningkatkan pemebelajaran tentang pengukuran melalui penerapan pendekatan concrete representational abstract (CRA), dan (3) mendeskripsikan kendala dan solusi dalam penerapan pendekatan concrete representational abstract (CRA) untuk meningkatkan pembelajaran tentang pengukuran pada siswa kelas IV SDN 1 Jerukagung. Penelitian ini adalah penelitian tindakan kelas kolaboratif yang dilaksanakan dalam tiga siklus dengan tahap perencanaan, pelaksanaan, pengamatan, dan refleksi. Subjek penelitian ini adalah siswa IV SDN 1 Jerukagung dengan 21 siswa. Data penelitian ini berasal dari guru dan siswa. Teknik pengumpulan data dalam penelitian ini menggunakan observasi, wawancara, dan tes. Validitas data dalam penelitian ini menggunakan teknik triangulasi sumber dan triangulasi teknik. Hasil penelitian ini menunjukkan bahwa pendekatan CRA dapat meningkatkan hasil belajar Matematika tentang pengukuran pada siswa kelas IV SD. Pada siklus I hasil observasi terhadap guru memperoleh persentase $65,49 \%$, dengan banyaknya siswa yang tuntas yaitu $73,81 \%$. Pada siklus II hasil observasi terhadap guru memperoleh persentase $75,00 \%$, dengan banyaknya siswa yang tuntas yaitu $78,57 \%$. Pada siklus III hasil observasi terhadap guru memperoleh persentase $83,92 \%$, dengan banyaknya siswa yang tuntas yaitu $92,86 \%$.
\end{abstract}

Kata kunci: concrete, representational, abstract, pembelajaran, pengukuran 


\section{PENDAHULUAN}

Matematika dapat diartikan sebagai kajian yang memiliki objek abstrak yang dibangun melalui penalaran deduktif, yaitu kebenaran suatu konsep diperoleh sebagai akibat logis dari kebenaran yang sudah diterima sebelumnya, sehingga kebenaran antar konsep dalam matematika bersifat sangat kuat dan jelas (Wahyudi, 2008: 3).

Mata pelajaran matematika pada satuan pendidikan sekolah dasar meliputi berbagai aspek yaitu aspek bilangan, aspek geometri dan pengukuran, serta pengolahan data (BSNP, 2006: 148). Pada aspek geometri dan pengukuran terdapat materi tentang pengukuran yang harus dipahami oleh siswa kelas IV sekolah dasar.

Berdasarkan hasil observasi yang dilakukan oleh peneliti terhadap siswa kelas III di SDN 1 Jerukagung pada tanggal 8 Juni tahun 2016 beberapa nilai matematika siswa masih di bawah KKM. Dari data yang diperoleh nilai ulangan kenaikan kelas mata pelajaran matematika tahun pelajaran 2015/2016 siswa kelas III SDN 1 Jerukagung rata-ratanya hanya 65 . Nilai rata-rata tersebut masih tergolong rendah karena belum melebihi Kriteria Ketuntasan Minimal (KKM) yaitu 70. Dari data siswa yang berjumlah 21 anak, terdiri dari 14 siswa laki-laki dan 7 siswa perempuan, masih terdapat 15 siswa yang nilainya masih di bawah KKM, sedangkan 6 siswa yang lain sudah memperoleh nilai di atas KKM. Perbandingan antara siswa yang belum tuntas dan yang sudah tuntas adalah 5:2. Sedangkan prosentase siswa yang tuntas hanya $29 \%$ dari 21 siswa dan $71 \%$ dari 21 siswa belum mencapai batas nilai ketuntasan minimal.

Selain itu, kesulitan yang dialami siswa dalam memahami konsep matematika diduga disebabkan oleh beberapa faktor, di antaranya: (1) penanaman konsep matematika pada setiap materi yang disampaikan guru masih minim; (2) guru tidak memperhatikan tahap-tahap belajar yang sesuai dengan karakteristik siswa; (3) pendekatan pembelajaran yang diterapkan oleh guru pada waktu kegiatan pembelajaran masih sebatas memberikan informasi/pengetahuan; (4) proses pembelajaran selalu berpedoman pada buku materi; dan (5) jarang mengaitkan materi pembelajaran dengan kenyataan atau pengalaman yang dialami siswa.

Apabila kondisi pembelajaran tetap dibiarkan, dikhawatirkan tujuan pembelajaran matematika tidak akan tercapai secara maksimal. Dalam hal ini, peneliti menerapkan pendekatan Concrete Representational Abstract (CRA) sebagai alternatif untuk memperbaiki proses pembelajaran matematika kelas IV SD terutama dalam mempelajari materi tentang konsep abstrak pengukuran yang perlu dipelajari mulai dari konsep konkret pengukuran, kemudian konsep representasi pengukuran, dan konsep abstrak pengukuran. Hal tersebut dilakukan secara bertahap agar penguasaan konsep tentang pengukuran dapat dipahami oleh siswa sehingga tujuan pembelajaran yang diinginkan dapat dicapai dengan maksimal.

Berdasarkan latar belakang di atas, rumusan masalah dalam penelitian ini adalah (1) bagaimana langkah-langkah penerapan pendekatan Concrete Representational Abstract (CRA) untuk meningkatkan pembelajaran matematika tentang pengukuran pada siswa kelas IV SDN 1 Jerukagung tahun pelajaran 2016/2017? (2) apakah penerapan pendekatan Concrete Representational Abstract (CRA) dapat meningkatkan pembelajaran matematika tentang pengukuran pada siswa kelas IV SDN 1 Jerukagung tahun pelajaran 2016/2017? (3) apa kendala dan solusi penerapan pendekatan Concrete Representational Abstract (CRA) untuk meningkatkan pembelajaran matematika tentang pengukuran pada siswa kelas IV SDN 1 Jerukagung tahun pelajaran 2016/2017?

Tujuan penelitian ini adalah (1) mendeskripsikan langkah-langkah penerapan pendekatan Concrete Representational Abstract (CRA) untuk meningkatkan 
pembelajaran matematika tentang pengukuran pada siswa kelas IV SDN 1 Jerukagung tahun pelajaran 2016/2017 (2) meningkatkan pembelajaran matematika tentang pengukuran dengan penerapan pendekatan Concrete Representational Abstract (CRA) pada siswa kelas IV SDN 1 Jerukagung tahun pelajaran 2016/2017 (3) mendeskripsikan kendala dan solusi penerapan pendekatan Concrete Representational Abstract (CRA) untuk meningkatkan pembelajaran matematika tentang pengukuran pada siswa kelas IV SDN 1 Jerukagung tahun pelajaran 2016/2017.

\section{METODE}

Penelitian ini merupakan penelitian tindakan kelas yang dilaksanakan di SDN 1 Jerukagung Kecamatan Klirong, Kabupaten Kebumen tahun ajaran 2016/2017. Subjek penelitian ini adalah siswa kelas IV semester I. Jumlah siswa sebanyak 21 siswa, yang terdiri dari 7 siswa laki-laki dan 14 siswa perempuan.

Data berasal dari siswa kelas IV dan guru kelas IV. Teknik pengumpulan data menggunakan observasi, wawancara, dan tes. Validitas data menggunakan triangulasi sumber dan triangulasi teknik. Teknik analisis data pada penelitian ini sesuai dengan pendapat Sugiyono (2012: 338-240), yaitu reduksi data, penyajian data, dan penarikan kesimpulan. Penelitian ini dilaksanakan selama tiga siklus, yang terdiri dari dua pertemuan pada tiap siklus. Arikunto, Suhardjono dan Supardi (2008: 16) mengemukakan PTK menggunakan prosedur penelitian yang terdiri atas empat tahapan, yaitu perencanaan, pelaksanaan, pengamatan, dan refleksi

Indikator capaian penelitian ini yaitu: (1) penerapan strategi REACT dengan media visual terhadap guru dengan target $\geq 85 \%$, (2) peningkatan hasil belajar matematika tentang pengukuran $\geq 85 \%$ dari jumlah siswa yang mendapat skor $\geq 70$.

\section{HASIL DAN PEMBAHASAN}

Penelitian ini merupakan penelitian tindakan kelas yang dilaksanakan di SDN 1 Jerukagung Kecamatan Klirong, Kabupaten Kebumen tahun ajaran 2016/2017. Subjek penelitian ini adalah siswa kelas IV semester I. Jumlah siswa sebanyak 21 siswa, yang terdiri dari 7 siswa laki-laki dan 14 siswa perempuan.

Data berasal dari siswa kelas IV dan guru kelas IV. Teknik pengumpulan data menggunakan observasi, wawancara, dan tes. Validitas data menggunakan triangulasi sumber dan triangulasi teknik. Teknik analisis data pada penelitian ini sesuai dengan pendapat Sugiyono (2012: 338-240), yaitu reduksi data, penyajian data, dan penarikan kesimpulan. Penelitian ini dilaksanakan selama tiga siklus, yang terdiri dari dua pertemuan pada tiap siklus. Arikunto, Suhardjono dan Supardi (2008: 16) mengemukakan PTK menggunakan prosedur penelitian yang terdiri atas empat tahapan, yaitu perencanaan, pelaksanaan, pengamatan, dan refleksi

Indikator capaian penelitian ini yaitu: (1) penerapan strategi REACT dengan media visual terhadap guru dengan target $\geq 85 \%$, (2) peningkatan hasil belajar matematika tentang pengukuran $\geq 85 \%$ dari jumlah siswa yang mendapat skor $\geq 70$.

\section{SIMPULAN}

Berdasarkan hasil penelitian dapat disimpulkan bahwa penerapan pendekatan CRA terbukti efektif dalam meningkatkan pembelajaran dan hasil belajar siswa kelas IV pada mata matematika dengan materi pengukuran di SDN 1 Jerukagung tahun ajaran 2016/2017. 


\section{DAFTAR PUSTAKA}

Aisyah, N. (2007). Pengembangan Pembelajaran Matematika SD. Jakarta: Dirjen Dikti Depdiknas.

Anitah, S. (2009). Teknologi Pembelajaran. Surakarta: Yuma Pustaka.

Anstrom, T. (2007). Supporting Students in Mathematics Through The Use of Manipulatives. American Institutes for Research, 1-15. Diperoleh pada 6 Juni 2016, dari http://www.cusdmathcoach.com/Supporting Students in Mathematics Through the Use of Manipulatives.pdf.

Arikunto, S. (2010). Prosedur Penelitian: Suatu Pendekatan Praktik. Jakarta: Rineka Cipta.

Badan Penelitian dan Pengembangan Pusat Kurikulum, Departemen Pendidikan Nasional. (2007). Kajian Kebijakan Kurikulum Mata Pelajaran Matematika. Diperoleh pada 6 Juni 2016, dari https://hasanahworld.files.wordpress.com/2012/04/50_kajian-kebijakankurikulum-matematika.pdf.

Badan Standar Nasional Pendidikan. (2006). Standar isi untuk Satuan Pendidikan Dasar dan Menengah, Standar Kompetensi dan Kompetensi Dasar SD/MI. Jakarta: Departemen Pendidikan Nasional.

Cope, L. (2015). Math Manipulatives: Making The Abstract Tangible. Delta Journal of Education, 5 (1), 10-19.

Fyfe, E.R., et al. (2014). Concreteness Fading in Mathematics and Science Instruction: a Systematic Review. Educational Psychology Review, 26 (1) 9-25.

Heruman. (2007). Model Pembelajaran Matematika di Sekolah Dasar. Bandung: PT Remaja Rosdakarya.

Hoong, L.Y., Kin H.W., dan Pien C.L.. (2015). Concrete-Pictorial-Abstract: Surveying Its Origins and Charting Its Future. The Mathematics Educator, 16 (1), 1-19.

Karso, dkk. (2013). Pendidikan Matematika I. Tangerang Selatan: Universitas Terbuka.

Kunandar. (2012). Langkah Mudah Penelitian Tindakan Kelas sebagai Pengembangan Profesi Guru. Jakarta: Rajawali Pers.

Mustakim, B., dan A. Astuty. (2008). Ayo Belajar Matematika Untuk SD dan MI Kelas IV. Jakarta: Departemen Pendidikan Nasional.

Putri, H.E. (2015). The Influence of Concrete Pictorial Abstract (CPA) Approach to The Mathematical Representation Ability Achievement of The Pre-Service Teachers at Elementary School. International Journal of Education and Research, 3 (6), 113-126.

Sagala, S. (2014). Konsep dan Makna Pembelajaran. Bandung: Alfabeta.

Sobur, A. (2010). Psikologi Umum dalam Lintasan Sejarah. Bandung: Pustaka Setia.

Steedly, K. et al. (2008). Effective Mathematics Instruction. National Dissemination Center for Children with Disabilities: Evidence for Education, 3 (2) 1-12.

Suharjo. (2006). Mengenal Pendidikan Sekolah Dasar. Jakarta: Departemen Pendidikan Nasional. 
Sugiyono. (2009). Metode Penelitian Kuantitatif, Kualitatif, dan R\&D. Bandung: Alfabeta.

. (2011). Metode Penelitian Kuantitatif, Kualitatif, dan R\&D. Bandung: Alfabeta.

Susanto, A. (2013). Teori Belajar dan Pembelajaran di Sekolah Dasar. Jakarta: Kencana.

. (2015). Teori Belajar dan Pembelajaran di Sekolah Dasar. Jakarta: Kencana.

The Access Center. (2010). Concrete Representational Abstract Instructional Approach. American Institutes for Research, 1-6. Diperoleh pada 23 April 2016, dari https://dwwlibrary.wested.org/media/concrete-representational-abstract-crainstruction.html.

Tim Penyusun Kamus Pusat Bahasa. (2002). Kamus Besar Bahasa Indonesia. Jakarta: Balai Pustaka.

Wahyudi. (2008). Pembelajaran Matematika di Sekolah Dasar. Surakarta: UNS Surakarta.

. (2013). Pembelajaran Matematika di Sekolah Dasar 2. Surakarta: UNS Press.

Witzel, B.S., Cecil D. Mercer, dan M. David Miller. (2003). Teaching Algebra to Students with Learning Difficulties: An Investigation of an Explicit Instruction Model. Learning Disabilities Research \& Practice, 18 (2), 121-131. 